\title{
Queen Vashti: A Contemporary Model for Christian Morality in Africa
}

\author{
Daniel Nii Aboagye Aryeh (iD 1 \& George Sungadar Moses Wee ${ }^{1}$ \\ ${ }^{1}$ Perez University College,Winneba, Ghana.
}

\begin{abstract}
In this paper, King Artaxerxes' action against Queen Vashti (Esther 1:1-2:1-18) is examined, and moral and ethical lessons for contemporary Christian morality are drawn. One can describe the decision of the King as contemptible, despicable, barbaric, and a violation of Queen Vashti's self-value and dignity. A further challenge can be thrown to the popular notion, which seems to suggest that Queen Vashti was disobedient, arrogant, and not submissive. Contrary to the traditional popular derogatory assessment of Queen Vashti's rejection of the King's demand, it is argued that she is a contemporary model for Christian Morality. Rhetorical criticism and historical narrative criticism were used for the study. An analysis of the moral and ethical factors that underpinned Queen Vashti's rejection of the King's demand and found that she demonstrated high moral and ethical values worth emulating was conducted in the study. It is, therefore, recommended that Christian women emulate Queen Vashti and maintain high moral and ethical values in society.
\end{abstract}

Correspondence:

Daniel Nii Aboagye Aryeh

Email: danielniiaboagyearyeh@ gmail.com

Publication History

Received 28th July, 2020,

Accepted 22nd October, 2020

Published online 11th February, 2021.

Keywords: King Artaxerxes, Esther, Vashti, Gender.

\section{INTRODUCTION}

The story of Queen Vashti is an interesting story for Christians, most especially male Christians who place irrevocable emphasis on the submission of women. The traditional popular view of Queen Vashti's refusal to accept the demand of her husband, the King, is that the Queen was disobedient, arrogant, not submissive and that she deserved to be dethroned as Queen. Others have viewed the narrative using a one-sided approach and eulogize Esther as the most favored celebrity. ${ }^{1}$ Contrary to the traditional popular derogatory assessment of Queen Vashti's rejection of the King's demand, the authors argue that she is a contemporary model for Christian Morality. Only hailing Esther and turning a blind eye on Queen Vashti's strong moral resilience is discriminatory and unjustifiable as far as Christian morality is concerned. It is agreed that God used the situation to deliver his people in exile. However, the authors hold the view that Queen Vashti has not been treated fairly by the traditional view and one-sided engagement of the narrative. The moral stance of Vashti has not been recognized. This paper is, therefore, designed to take another look at the narrative (Esther $1: 1-2: 1-18)$.

The method used for this study is eclectic: the amalgamation of rhetorical criticism and historical narrative analysis. Rhetorical criticism is used for the analysis of the Esther narrative, while historical narrative analysis is used for the discussion of gender-free expression in the African context. Rhetorical and historical narrative criticisms were used to analyze the moral and ethical factors that underpinned Queen Vashti's rejection of the King's demand to appreciate Queen Vashti's contribution that could influence contemporary Christian morality and ethical values.

This paper makes a significant contribution to scholarship by highlighting the forgotten contribution of Queen Vashti to morality in society. It also argues for the free expression by women in society without the fear of victimization. The study focuses particularly on the undercurrents of the decision of Artaxerxes - taking decisions under the influence of alcohol and the respect for free expression of women. It is advocacy for Queen Vashti; she was a victim of patriarchal

Susan Zaeske, "Unveiling Esther as a Pragmatic Radical Rhetoric”, Philosophy \& Rhetoric, Vol. 33, No. 3 (2000): 193-220. 
violence of a society that does not allow women to express their thoughts without fear. To investigate the undercurrents of the decision of King Artaxerxes to dethrone Vashti and enthrone Esther, the historical background and literary context of Esther is examined; a discussion is also on the decision of the King in the context of banquets by political leaders in the Ancient Near East (ANE); an analysis of the refusal of Queen Vashti in the context of patriarchal domination is also conducted, and a further discussion is drawn on the selection of Esther through a beauty contest to become Queen in a foreign territory. The article then draws implications for gender-free expression in contemporary Christian society in Ghana.

\section{The Esther Narrative}

The literature on Vashti's moral values and integrity are scanty. The available literature on the liberation of the Jews in exile in Persia focuses on the exploits of Esther and the Jewish people. In fact, the book of Esther is biblical evidence of this phenomenon. The narrative concerning the exploits of Esther and the Jewish people in exile is usually studied from the perspective of the power of Yahweh to deliver His people from the bondage of their oppressors. Zaeske used a rhetorical literary approach to study the book of Esther, particularly the selection and enthronement of Esther (1:1-2:118). Her objective was to disclose how Yahweh is able to raise the status of marginalized people in exile to prominence. ${ }^{2}$ In gender terms, Zaeske focused on the discourse and action of Queen Vashti and Esther. Queen Vashti was a Gentile, who was privileged, and Esther was a Jew (the people of Yahweh), who was marginalized together with all the Jews in exile. Eventually, Esther, who was a foreigner, gained an advantage over the indigenous Queen Vashti and became a Queen instead of Vashti. Zaeske referred to this as "a rhetoric of empowerment," ${ }^{3}$ rhetoric of the empowerment of the exiled over their colonial master or oppressors. Drawing lessons from her study of the Esther and Queen Vashti narrative, Zaeske concluded that the empowerment of marginalized people in exile must be applied to "Jews, women, African-Americans, and lesbians."

In a comparative study of queenship in the ancient world with a particular interest in Esther and Jezebel, Zlotnick stated that:

....as a biblical narrative recreates Jewish queenship in the scrolls of Esther, the leading female character undergoes the same kind of transformation that underlies Tanaquil-to-Tullia process, but in reverse. To begin with, Esther is not only Jewish but a woman with impeccable royal (Jewish) blood in her veins. Jezebel is constantly branded a foreigner in a manner that reflects not only her ethnicity but also her proclivities. ${ }^{5}$

Esther was depicted to have had royal blood in her vein, and that was what made her queenship in foreign land imperative. There is no biblical evidence to support this assertion. It could be described as a conjecture based on the unflinching trust of the Jewish people in the provision of Yahweh. It could be that the Jewish religious leaders who revised the Esther narratives believed that she could not have been made a queen in a foreign land if she did not have that blood in her veins. That royal blood, which may be metaphorical, is a supernatural provision by God because there is no proof that Esther hailed from a royal family. Even if she hailed from a royal family, she would be expected to marry a King in Israel, not in Persia. There is also no evidence to show that women who hail from royal homes would necessarily get married to a male of royal descent. The reshaping of the Esther narrative, as portrayed in the work of Zlotnick, seeks to suggest that Yahweh highly favored Esther, which was why she became queen instead of Vashti.

Fader $^{6}$ discussed the beauty of Esther in the context of ethnography as the basis for contemporary Jewish girls to appear in a daggling manner during the celebration of the Purim festival. His work attempted to present the apparel of Esther as a Jewish norm; however, the one-year beauty therapy, which Esther observed, is not Jewish. Fader suggests that the selection of Esther to be queen in a foreign land was due to her style of dressing that was resoundingly attractive to the King and his advisers. Oren ${ }^{7}$ similarly posits that the human body of Esther was fashioned in a manner that was used by God to liberate the Jewish people from being annihilated by Gentiles. His view suggests that the body of Esther was a mixture of Jewish and Persian filial aesthetic. It explains why a Jewish lady would be married to a Gentile King, which is perceived to be orchestrated by God. However, Jews were not allowed to marry non-Jews. The postulation of Oren demonstrates that Yahweh could break His commandment in the face of threatening potentials to annihilate His chosen people - Israel. ${ }^{8}$

Bahar likened the liberation of the Jews to a homosexual person who lived in a socially excluded society and eventually was accepted by society. In other words, the Jews in exile are likened to the socially marginalized people

\footnotetext{
Zaeske, "Unveiling Esther as a Pragmatic Radical Rhetoric"214.

Zaeske, "Unveiling Esther as a Pragmatic Radical Rhetoric"214.

Zaeske, "Unveiling Esther as a Pragmatic Radical Rhetoric"194.

Helena Zlotnick, "From Jezebel to Esther: Fashioning Images of Queenship in the Hebrew Bible", Biblica, Vol. 82, No. 4 (2001), $477-495$.

Ayala Fader, "Reflection of Esther: The Politics of Jewish Ethnography" in Contemporary Jewry, Vol. 27, No. 1 (October 2007), 112-136.

Drora Oren, "Esther-The Jewish Queen of Persia," Nashim: A Journal of Jewish Women's Studies \& Gender Issues, No. 18, (Fall 2009): 140-165.

"Esther-The Jewish Queen of Persia,", 144.
} 
based on their sexual preference, illness, disability, etc., who have been eventually accepted back in society to enjoy a royal treat. Her work was mainly concentrated on gender and human sexuality in the context of royalty. ${ }^{9}$ It raises the question of how could a King divorce his native indigenous wife at the least provocation and get married to a foreign lady. Probably, the King was attracted by sex and beauty. Walfish ${ }^{10}$ analyzed the authenticity of the story of Esther in the Babylonian Talmud and other ancient manuscripts. He argues that Esther was married to Mordecai prior to her consensual erotic relationship with King Artaxerxes. In that regard, Esther was not a virgin when she contested for the queenship. He further observed that the story of Esther as a queen to Artaxerxes does not exist in Persia. The work of Walfish clearly compared the biblical story with other ancient texts to reconstruct the story. However, for the basic fact that there is no evidence for the existence of the narrative of the marriage between Esther and the King in Persia does not indicate that it did not take place. Probably, it was not recorded or kept in the annals of the kingdom because it praises a foreigner - Esther at the detriment of their native queen - Vashti. This phenomenon has the potential of creating a canon within the canon of Scripture. ${ }^{11}$

The work of Zaeske, Zlotnick, Fader, Oren, and Bahar generally emphasized the empowerment of the Jewish people in exile through the beauty and the help of Yahweh for the rise of Esther to queenship, which led to the liberation of the Jewish people in a foreign land. They mainly emphasized the empowerment of marginalized people to the centre of social privilege and strata. It is an ethno-religious interpretation of the Esther-Vashti narrative that depicts the favoritism of Yahweh towards Israel. The works reviewed emphasized the liberation of the oppressed but failed to see the role of Vashti in the quest for the liberation of women from patriarchal oppression. They did not analyze the undercurrents of the decision of King Artaxerxes and its implications for Christian ethics and morality today. Vashti defied what she considered as violence to her integrity as a woman. She left a true legacy that could be relevant to women in oppressive patriarchal societies such as those of Africa.

At the point that the King asked that Queen Vashti was commanded to show her nakedness to the guests of the King, she was hosting guests at her cottage for a banquet. Is it that her banquet was perceived to be running counter to the King's? That is why she was asked to come and entertain the Kings' guest in order to collapse her banquet? Can the text be read in favor of Queen Vashti of being deprived of her position through the influence of intoxication and male political power? Can women express their decision without falling victim to the anger of men? The works reviewed so far suggest that Vashti's contribution to moral value has been sidelined. Therefore, there is the need to undertake a study that interprets the narrative in the context of Queen Vashti and draw ethical and moral implications for contemporary Christian society in Ghana.

\section{Historical Background and Literary Context of Esther}

The book of Esther is diasporan literature of the Jews. The book did not specifically mention God. However, God was perceived to be behind many of the scenes in the book, to bring deliverance and freedom to the Jews in a foreign land - Persia. Stern avers that the book of Esther is an exilic book whose audience is the Jews in exile. ${ }^{12}$ In that regard, there was no mention of significant Jewish features - the land of Israel, the Temple, and the priest. However, the dominant use of Hebrew to write the book instead of balanced bilingual feats that characterizes diasporic literature has forced other scholars to think that the book was not written with the diaspora Jews in mind. ${ }^{13}$ Nonetheless, the majority of scholars accept the position that it was written in the diaspora for the Jews in the diaspora. Oren opined that the cultural behavior of feasting and the use of selected spices and oils to enhance feminine beauty support diasporic literature intended for the Jews in a foreign land. ${ }^{14}$ The book presents the setting and context of the banquet as the occasion where many landmark decisions were taken. It reports a total of 11 banquets $(1: 3,5,9 ; 2: 18 ; 5: 4,5,8,12,14,6: 14 ; 7: 8)$, as against 10 mentioned by Oren. ${ }^{15}$

Repetition of terms in literary criticism serves as a means of consolidating the meaning of the term throughout the material. It is a rhetorical device employed to attract the attention of listeners or readers to the argument of the author. Depending on the circumstances or the cause that merit the situation, repetition can be progressive (positive) and regressive (negative). Leroux refers to both progressive and regressive repetition as a syllogistic progression form. ${ }^{16}$ Repetition always makes reference to the past in new forms and contexts. The repetition of the banquet in the book of Esther is progressive towards the Jews and regressive towards the enemies of the Jews. Oren succinctly puts it thus:

\footnotetext{
Shirley M. A. Bahar, “Coming out as Queen: Jewish Identity, Queer Theory, and the Book of Esther”, Studies in Gender and Sexuality, 13:3, 167-178. http//dx.doi.org/10.1080/15240657.2012.709134.

10 Barry Dov Walfish, "The Mordecai-Esther-Ahasuerus Triangle in Midrash and Exegesis”, Prooftexts, Vol. 22 , No. 3 (Fall 2002 ), $305-333$.

11 Walfish,The Mordecai-Esther-Ahasuerus, 331.

Elsie R. Stern, "Esther and the Politics of Diaspora," The Jewish Quarterly Review, Vol. 100, No. 1 (Winter, 2010): 25-53.

Stern, "Esther and the Politics of Diaspora," 26-27.

Oren, "Esther-The Jewish Queen of Persia," 143.

Oren, "Esther-The Jewish Queen of Persia,", 144.

Neil R. Leroux, "Repetition, Progression, and Persuasion in Scripture,” Neotestamentica, Vol. 29, No. 1 (1995), 1-25.
} 
The banquet becomes a tool in the hands of the powerful one who has a plan and a strategy to accomplish his/her political wishes, to classify who is "in" and who is "out" in Persian society. The subsequent banquets, initiated by others, effect shifts in power only because the omnipotent king originated the first banquet. The narrative's move from one banquet to the next marks these shifts in power. ${ }^{17}$

The main character in the text is Esther, who was also referred to as Hadassah. The minor characters in the narrative include King Artaxerxes, Mordecai, and Queen Vashti. The character is chiastically demonstrated in the first two chapters of the book, which happens to be the text for this study:

A Vashti's banquet (1:9)

B Crowning of Vashti (1:10-11)

C Vashti's refusal (1:12)

D Advisers suggest the replacement of Vashti; and Artaxerxes' edict (1:13-22)

E Advisers proposal for a beauty contest; and Artaxerxes' edict (2:1-4)

F Introduction of Esther and Mordecai (2:5-7)

E' Collection of women for beauty contest (2:8-11)

D' Replacement of Queen Vashti (2:12-15)

C' Esther in the presence of King Artaxerxes (2:16)

B' Crowning of Esther (2:17)

A' Esther's banquet $(2: 18)^{18}$

McCoy traces the history of chiasmus or chiasm to the period of the Sumero-Akkadian period and Ugaritic text during the third millennium BCE. ${ }^{19}$ When two clauses are mirrored against each other, and two diagonal lines are drawn across, the point of intersection or meeting is the chiasm. In the chiasmus diagram above, the point at which the two parts of the narrative in chapters 1 and 2 meets is "F"- the introduction of Esther and Mordecai or the rise of Esther and Mordecai to prominence and power. Consequently, it can be conveniently argued that the book projects the rise of the Jewish people in a foreign land, which points to the most critical issue in the Esther story. It is a chiasmus with a central point. This form of chiasmus usually has two halves of a story with a central statement that distinguishes the two halves and at the same time shows the link between the two. The second half of the text is an inverted parallel of the first half. ${ }^{20}$ Assis states that it "is a rhetorical device that focuses the reader's attention on the center of the unit, where the central idea or turning point is situated. Awareness of chiasmus enables the reader to uncover the meaning of the literary unit." ${ }^{21}$ Each line of the statement in the chiasmus diagram above is a topic that have been discussed by many scholars. The highest point of the chiasmus " $F$ " is what mainly influence the interpretations of the Esther-Vashti narrative that always places Esther and the Jewish people in exile above all odds.

\section{Intoxicated King Artaxerxes}

King Artaxerxes was also known as Ahasuerus. The name Ahasuerus is the Hebrew version of Greek corrupted form of Artaxerxes as used in the LXX - $\alpha \rho \tau \alpha \xi \varepsilon \dot{\varepsilon} \rho \eta \varsigma^{22}$. This study preferred the LXX designation due to the centrality of the LXX to both the Hebrew and the Greek texts. ${ }^{23}$ King Artaxerxes was referred to as Xerxes in the book of Daniel and Nehemiah. On the seventh day of a particular banquet, King Artaxerxes was drunk with wine, (1:10) ("the King's heart was merry with wine"). It implies that the centre of decision making of the King had been taken over and controlled by alcohol. Therefore, the decision of the King has to be understood in the context of the influence of intoxicating wine. Bahar states that "banquets and booze, comprising a repetitious motif in the text, set the scene for Esther's coming out: her interlocutor is therefore drunk, unstable, and unreliable, traits that only add to his already established derogatory image as a farcical King in the text." ${ }^{24}$ The view of Bahar shows that there is an inseparable bond between banquets and boozing. Alternatively put, there is a progressive relationship between banqueting and boozing. It can mathematically be expressed thus boozing is a subset to a banquet, the banquet is the main set.

\footnotetext{
17 Oren, "Esther-The Jewish Queen," 144-145.

18 Clinton J. Moyer, “The Beautiful Outside Replaces the Queen: A 'Compound Topos' in Esther 1-2 and Book 5 and 6 of Chariton's Chaereas and Callirhoe,” Vetus Testamentum, 60 (2010), 601-620. 605.doi:10.1163/156853310X527824

19 Brad McCoy, "Chiasmus: An Important Structural Device Commonly Found in Biblical Literature," 1-12. accessed March 22, 2016 on www.chafer.edu/journal/back_issues/Vol\%209-2\%20ar2.pdf.

20 For procedure for determining a chiasmus or chiasm, see Yitzhak Berger, "Chiasm and Meaning in 1 Chronicles," Journal of Hebrew Scriptures Vol. 14, No. 1 (2014), 1-31.

21 Elie Assis, "Chiasmus in Biblical Narrative: Rhetoric of Characterization”, Prooftexts Vol. 22, No. 3 (Fall 2002): $273-304$.

22 Moyer, "The Beautiful Outside," 604.

23 Although some Jews do not like the LXX due to the belief that the translation missed out on some issues in the MT, many Greek speaking Jews and non-Jews preferred it. This makes the LXX acceptable to varied range of people.

24 Bahar, "Coming out as Queen," 171.
} 
Banquets in Persia is the occasion for the demonstration of foods and drinks, and one's political and social influence over the other. An occasion for the politically powerful person to take decisions over others; decisions that indicate the status of government officials, citizens, and wives. It is significant to add that Persians were noted for making decisions while drunk at the banquet. ${ }^{25}$ Hence, it was expected by the guests that the King would decide on someone to the advantage of the other. Although it is a cultural issue, it suggests that the decisions of the King during banquets were not from his right frame of mind but being influenced by alcohol abuse. He may consult his advisers, but many of them might likely be intoxicated as-well. The question that may emanate from the lips of others (non-Persians) at the time is that how sound would these decisions be?

The act of King Artaxerxes is similar to a popular saying in the Akan language (numbi na kika bi kyere waasi), which literally implies that 'take some hot intoxicating/alcoholic beverage in order to speak harshly and culturally indecorous to your mother-in-law.' In other words, decisions made during moments of being controlled by external elements (alcohol), are not critically thought through. "The order of unrestricted drinking symbolizes the King's aspiration for unrestricted power over his subjects....In spite of the King's efforts to manipulate his subjects with wine, he runs the risk of losing control, especially when he is intoxicated." ${ }^{26}$ However, it can be argued that King Artaxerxes used a laid down socio-politico-cultural norm to show that he is the most powerful in the kingdom of Persia. This norm is influenced by patriarchy, and gender injustice, which should not be emulated by contemporary Christian men/males who are in political positions or are the main providers of financial and other resources in a marital relationship. This norm can be considered as making a decision under duress.

\section{Refusal of Queen Vashti}

How Queen Vashti attained her status as a wife of King Artaxerxes is not stated in the book. However, since she often organizes banquets for her maidens and subjects (1:3), which was a norm in Persian politics and social life, she was likely an indigenous Persian. It is not clear whether the King and the Queen can hold banquets concurrently at different venues in the kingdom, with different guests at the same time. However, the use of the pi'el tense to describe the refusal

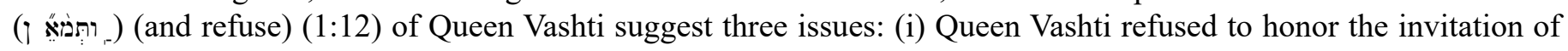
King Artaxerxes in a derogatory manner, which is abnormal in Persian society; (ii) she was competing with the King, because at the time that the King asked for her, she was chairing a dinner for her guests, maidens, and subjects. A kind of power play, where (iii), (i), or (ii) had an indelible influence on the position of the King as the political head and husband. This is obvious in the advice given to King Artaxerxes that refusal to punish Queen Vashti will serve as an example for other women to disregard their husbands' requests (1:16-18). Rhetorically, if the King did not take action against the queen, it would have politically and socially appeared that the queen was more powerful than the king.

The implication of the action of Queen Vashti was interpreted by the intoxicated advisers of King Artaxerxes to jeopardize family harmony in the kingdom of Persia. ${ }^{27}$ This implies that the King's advisers felt threatened that the Queen's refusal would potentially influence the liberation of women from the subjugation of men. Surprisingly, King Artaxerxes accepted the advice of his co-intoxicants to banish Vashti from being Queen. "Vashti is presented as an unstable force, a disruptor of the natural order of things. ${ }^{28}$ In this case, natural order refers to an unquestionable response to any assertion by males in society. Some have suggested varied reasons why Queen Vashti refused to accept the invitation of the King. Some argued that the main reason for Queen Vashti's refusal was because she similarly had a banquet with her guests. This reason suggests a power struggle between the King and the Queen. Arguing from the Jewish ethnography account, Fader asserted that Queen Vashti did not attend to the King's call because she maltreated the Jewish slave girls who served her. Therefore, when she received the message from the King, she looked into the mirror to praise her beauty before going to the King's court. She then realized that she had become a monster; that is why she did not go to the King. ${ }^{29}$ Simply put, Vashti did not purpose in her heart to refuse the demand of the King but that Yahweh punished her for maltreating Jewish slaves. This is Jewish propaganda to show that the selection of Esther to queenship was the result of Yahweh's punishment of Queen Vashti for maltreating Jewish peoples. It is aimed at making Jews untouchable by any people or nation or kingdom. The foregoing reasons are perhaps the most unacceptable reasons for the interpretation of the refusal of Queen Vashti. Queen Vashti actually took a moral position, but she was not allowed to be heard. Even today, people are using spiritual and religious approaches to explain away Vashti's high moral integrity. "The king's advisors recognized that Vashti's bravery was fuel for other women to find their voices; they knew the positive influence of her courage." ${ }^{30}$

\footnotetext{
25 Stephen F. Noll, “Esther” in Walter A. Elwell (ed) Baker Commentary on the Bible Based on the NIV (Grand Rapids, Michigan: Baker Books, 1989), 328-329.

26 Oren, "Esther-The Jewish Queen," 143, 144.

27 Moyer, "The Beautiful Outside," 605.

28 Moyer, "The Beautiful Outside," 605.

29 Fader, "Reflection of Esther," 119.

30 Meredith J. Stone, “There's more than one way: Vashti, Esther, and women in ministry,” Review \& Expositor, Vol.110, No. 1 (2013): $123-130$.
} 
Beauty is one of the central issues in the book of Esther. It has to be displayed in public so that the politically powerful in society will feel that they have the most beautiful person in the kingdom as a wife. Rhetorically, Queens were expected to renew their relationship with the King "as beautiful, erotic objects" and not mates in drinking and eating in public. ${ }^{31}$ The king virtually asked the Queen to show her nakedness to the guests because she was fair ( (מור:אה (Est. 1:11). There is no record to show that Kings compel their wives to show themselves half-naked to their courtiers in banquets in Persia. In other words, the demand of the King was outrageous, out of societal norms. He might have been influenced by alcohol. His demand and decision would have been different if he and his advisers were not under the influence of alcohol.

To ask that the Queen should show herself nakedness in public is unethical, which many right-thinking women would not subject themselves to. In Africa and other jurisdictions, ladies who expose their nakedness in public are considered to be morally polluted, culturally unacceptable, or prostitutes. She was the wife of the King, not all men, and for such, her nakedness should be exclusive to the viewing of the King, not the public. Queen Vashti should be viewed as a woman with high integrity, one who risked her position to protect the integrity and dignity of women.

Nadar has rightly asserted that the Queen was invited to present herself before the King and his drunken guests as a sexual object and not a Queen simply because the King and his men were only interested in seeing her beauty. Her refusal subverted men's desire to objectify her as a woman. ${ }^{32}$ She exercised her freedom of choice and appropriated power to herself as an individual. For a woman to appropriate power in this manner is not expected and is perceived as a threat to men. Hence, a group of important but drunken men decided to banish Vashti from her role as Queen. Her defiance caused her to lose her position as Queen. Vashti exits the text upon her banishment, and the text does not mention her anymore in the book of Esther. However, her absence is powerful because she has exited the text without surrendering to the powers she perceived to be oppressive..$^{33}$

The King's action portrays intolerance, cruelty, and violence against the Queen. Generally, women love to be protected rather than being exposed to public ridicule and abuse. In this case, the King failed to protect the Queen and to respect her decision not to expose her nakedness to the public. The King might have wanted to show her to the public as the most beautiful lady in the kingdom, but the mode of showing that beauty was not appropriate.

\section{The Selection of Esther}

The name Esther is a Persian designation that emanates from the root "to hide." It reflects how she hides her identity as a Jew to the King and the Persians; Hadassah is the Hebrew version of Esther. ${ }^{34}$ The two names mentioned suggest unstable identity because the names of women were seldom mentioned in the Bible. ${ }^{35}$ Once Vashti was banished, there was a vacancy for the selection of a new Queen. The procedure for the selection of Esther was through a beauty contest as advised by the King's counselors (1:10-12). It presents a consensus that the lady that would be selected should be able to show herself half-naked in the presence of the King's courtiers during banquets. The decision for a Jewish lady to submit to a beauty contest in which the rules governing the contest do not resonate with her religio-cultural norms is very strange. The authors can only conjuncture under adaptations that Esther and the Jews in exile had adapted some foreign norms in other to survive because the religious and social structure of Persia differed from that of Israel. The political and social structures in Israel at the time suggest the amalgamation of theocracy and dynasty while Persia practiced pure dynasty.

It is generally believed that Esther was a virgin at the point of being selected, groomed, and won the beauty contest to become the Queen. Esther 2:17 suggests that the ladies gathered for the contest were not all virgins. They were ladies of marriageable age not necessarily virgins. It resonates with the concept and characteristics of a virgin in non-Jewish societies, which differs from the concept of a virgin in the Jewish context that depicts a lady who had not had sex. Drawing from the Babylonian Esther Midrash Walfish argued that prior to the beauty contest Esther was married to Mordecai. He stated that the document "portrays Esther, not as a young virgin, but as a mature woman who was already married to Mordecai when she was taken to the King's harem....Esther was Mordecai's niece to provide justification for his niece marriage....Esther moved from bed to bed, cleansing herself in between." ${ }^{36} \mathrm{He}$ further argued that there is no evidence in Persia concerning the marriage between Esther and King Artaxerxes. ${ }^{37}$ Walfish's statement seems to suggest that Esther was a harlot but there is no evidence to prove it. Although it is not usual for a Jewish lady to be married to a Gentile, the views of Walfish can hardly be substantiated since they can only be found in the Babylonian

\footnotetext{
31 Oren, "Esther-The Jewish Queen", 146.

32 Sarojini Nadar. "Power, ideology and interpretation/s: Womanist and literary perspectives on the Book of Esther as resources for gender-social transformation," (Doctoral dissertation), 2003. Retrieved from http://hdl.handle.net/10413/3449. Accessed November 20, 2019.

Nadar, Power, ideology and interpretation/s.

Bahar, "Coming out as Queen", 170.

Walfish, "The Mordecai-Esther-Ahasuerus Triangle", 157.

Walfish, "The Mordecai-Esther-Ahasuerus Triangle", 306, 307, 308.

Walfish, "The Mordecai-Esther-Ahasuerus Triangle", 305.
} 
Talmud Tractate Megillah. The relationship between Esther and Mordecai as to whether they were cousins or she was the niece of Mordecai is an issue that is beyond the scope of this study.

Based on the advice of the inebriated counselors of the King, commissioners in all the Regions of Persia were commanded to gather all young ladies to the King's harem $(2: 3,8)$. Hence, Esther had no choice to exempt herself since Mordecai supported her involvement in the contest. Mordecai's continuous instructions and monitoring of Esther (2:1011) point to the fact that Esther might have been a timid lady who could not reason independently. The twelve months of beauty therapy is not Jewish. However, it ought to be understood that Esther and her ethnic group were in a foreign land and had no choice. The decision to select a new queen through a beauty contest was to ensure that the incoming Queen would always accept the invitation of the King to show herself half-naked or completely naked in the presence of his courtiers during banquets. Being half-naked is not accepted in Jewish society not to even talk about complete nakedness. It raises issues of morality in a foreign land. Does it suggest that moral values could be suspended when one finds him/herself in a foreign context? The story of Esther suggests that God can use any situation to deliver his people. The unreasonable and immoral demand of the Persian King and the refusal of Queen Vashti to honor the invitation paved the way for Esther to capture the Persian throne. While one appreciates God for his intervention and deliverance of the Jews using Esther and Mordecai as instruments, the resilience of Queen Vashti to uphold morality and the dignity of women must not be pushed away. Such a resilient attitude and moral fortitude is needed in contemporary Christianity.

\section{Findings and Further Discussion}

The burgeoning argument suggests that the Esther-Vashti and the King's narrative is about political power and cultural norms of the genders. From a Political perspective, the refusal of Queen Vashti to show her nakedness to the public has been interpreted as an attempt to exert her political power. However, the narrative clearly shows otherwise. Queen Vashti did not argue against the King's decision. She did not mobilize women to revolt against the King's authority. Vashti was not interested in a power struggle with the King. She was rather willing to sacrifice and forfeit her throne in order to leave a legacy for all women. She serves as an example to women in situations of powerlessness through her defiance to become subject to men, even though it would cost her life. ${ }^{38}$

As Castelnuovo rightly explains, Vashti's sense of propriety, modesty, and queenly behavior took precedence over the command of the king. There appeared to be no political overtones. She did not issue a proclamation on women's rights; she did not publicly denounce the king on the basis of a higher law. ${ }^{39}$ The physical and psychological, explicit, and severe and inhumane treatment meted out against Vashti signifies the punishment extended to women who are brave, bold and influential in society.

The King was intolerant of a lady who desired to uphold the morality and dignity of women in Persia. The King did not respect the decision of the Queen not to show her nakedness in public. The King's action is attributable to complete intolerance and abuse of power. How on earth must a queen display her beauty to the amusement of drunken guests? The King and his guests were under the influence of alcohol. This is a demonstration of a king who lacked selfcontrol.

It is known that banquets served as social events where landmark decisions were taken in Persia. Hence, all prominent opinion leaders were expected to be present at such functions. For instance, Queen Vashti was banished during a banquet and a banquet was organized to accept Esther as Queen. In rhetorical terms, it is a polyptoton repetition that depicts the repetition of a term or a concept in varying contexts or for varied reasons. Kings were expected to make decisions at the end of a banquet. The decision could be progressive or regressive to a particular group of people or a person. In that regard, such decisions were taken when the King and his advisers were drunk. It follows the order thus: banquet $\rightarrow$ boozed $\rightarrow$ decision $\rightarrow$ promotion or demotion $\rightarrow$ ends in demonstrating the political and social power of the King. Unlike the King of Persia, in biblical times and even in Africa, kings are expected to make decisions that foster unity, justice, fairness and community development.

Finally, and most importantly, the narrative shows that Queen Vashti refused the order of the King on moral grounds and she served as a lone voice in the wilderness characterized by patriarchal domination. Vashti must be celebrated as a contemporary model for Christian morality in Africa, a continent in which Christians and traditional leaders eschew indecent dressing.

\section{Cultural Norms and Gender Power in Africa}

African society is generally patriarchal. Men are considered to be special creatures. Many traditional political positions are being held by men. When an African king makes a decision, it is deemed to have ancestral authorization; hence, his

\footnotetext{
Orlando E. Costas, "The Subversiveness of faith: Esther as a paradigm for a liberating theology," The Ecumenical Review, Vol. 40, No. 1 (1988): 66-78.

39 Shirley Castelnuovo, "The Jewish Experience of Oppression as Portrayed in the Hebrew Bible: Leadership and Survival Strategies. Jewish," Political Studies Review, Vol. 3, No. 1/2 (Spring 1991): 33-47.
} 
decision is not to be challenged in public. ${ }^{40}$ Emphasis is placed on the role of the ancestors as the author of morality and will punish immoral and ethically corrupt leaders. ${ }^{41}$ Due to the rigorous spiritual ritual that kings undergo before they are coroneted, they are considered to be both divine and human. Often the divine aspect of kings is projected above their humanity. Since they are human, there should be measures to check some decisions they make. Any decision that is intrigued by ethical and moral values and aimed at personal aggrandizement should not be allowed to operate. God is seen as the arbiter of ethical and moral value. "morality flows from God, and the nature of God demands an appropriate response from his creatures." ${ }^{42}$ Hence, the inhumane actions of Queen Vashti's husband, the King, must not be emulated by kings and men in political positions to perpetuate violence against women in Africa.

The demand by the King for Queen Vashti to appear naked in public is gender violence against women. Oduyoye argues that this form of violence is in the ascendency in the West African region. ${ }^{43}$ To ask a lady to show her nakedness for public viewing is tantamount to sexual harassment. "Sexual harassment is unwelcome sexual advances, request for sexual favors; and other verbal or physical conduct of a sexual nature." ${ }^{\prime 4}$ Hence, it will be inappropriate to use a religious document ${ }^{45}$ to perpetuate sexual abuse in the name of male-dominated political power. Christian masculinity and power must be used to protect the vulnerable including the sexual rights of citizens.

Vashti's action suggests a bold step to the liberation of women who have for so long marginalized in Africa, in politics, at home, at work, and even in the church. In the Christian Church, for instance, some Bible passages have been interpreted with prejudice to keep women at bay. Domestic violence, most especially violence against women, is replete in African society. Vashti's action echoes a call that such societal ills must come to an end, and women must learn to say no to the immoral demands of men in a non-violent manner. Women are generally soft and polite with strong acumen. These socially relevant virtues that good women exhibit have always being abused by men in society, whether in the classroom, politics, at home, or at work. Men must know that biologically softness does not mean being weak but rather being firm. There is a need to prioritize women's needs and give them premium attention. ${ }^{46}$

\section{Recommendations}

In view of the findings of the study, the authors recommend the following:

- Vashti's sense of propriety, modesty, and queenly behavior took precedence over the command of the King. She is a contemporary model for Christian Morality.

- The King's decision against Vashti is not only unacceptable but also contemptible, despicable, barbaric, and a violation of Queen Vashti's self-value and dignity.

- Queen Vashti demonstrated high moral and ethical values worth emulating.

- Christian women in Africa should emulate Queen Vashti and maintain high moral and ethical values in society.

\section{CONCLUSION}

This paper was designed to examine King Artaxerxes' action against Queen Vashti (Esther 1:1-2:1-18) and draw moral and ethical lessons for contemporary Christian morality. Rhetorical criticism and historical narrative criticism were used for the study. The narrative indicates that King Artaxerxes ordered Queen Vashti to displace her beauty in the presence of his drunken guests and the Queen refused to obey the King. The Queen was subsequently dethroned and another (Queen Esther) took her place. Queen Vashti's refusal to go naked and displace her beauty to the amusement of the drunken King and his drunken guests has received sharp condemnation from many. Some have described her as a disobedient and arrogant woman who lacked the virtue of submissiveness.

The authors analyzed the moral and ethical factors that underpinned Queen Vashti's rejection of the King's demand. Consequently, they have reached the conclusion that the traditional interpretation of Queen Vashti's action is inconsistent with Christian morality and that Queen Vashti should rather be celebrated for her high sense of morality and integrity. Many Christians hail Queen Esther (the Jewish woman) and turn a blind eye on Queen Vashti's strong moral resilience. This is discriminatory and unjustifiable as far as Christian morality is concerned. The authors agree that the narrative suggests that God used the Queen Vashti-King Artaxerxes' situation to deliver his people from exile. However, they hold the view that Queen Vashti has not been treated fairly by the traditional view, which suggests a one-sided

\footnotetext{
40 John S. Mbiti, Introduction to African Religion 2 2d Ed (Oxford: Heinemann Educational Publishers, 1991), 82-85; Kwame Gyekye, African Cultural Values: An Introduction (Accra: Sankofa Publishing Company, 1996), 109-111.

41 Kofi Asare Opoku, West African Traditional Religion (Accra: FEP International Private Limited, 1978), $155-156$.

42 Opoku, West African Traditional Religion ,153.

43 Mercy Amba Oduyoye, "Gender-Based Violence in Religiously Pluralistic Societies: The West African Experience", in Religion and Gender-Based Violence: West African Experience, Mercy Amba Oduyoye and Rose Mary Amenga-Etego eds (Legon: Legon Theological Studies Press, 2013 ): 1-19.

44 Ohia and Uche Nkiru Azikiwe, "The Church, Sexual Harassment and Abuse of Women in South-East Nigeria" in Religion and Gender-Based Violence: West African Experience, Mercy Amba Oduyoye and Rose Mary Amenga-Etego eds (Legon: Legon Theological Studies Press, 2013 ): 82-98.

45 Oduyoye, "Gender-Based Violence", 8-9.

46 Rose Uchem, Eradicating Gender-Based Violence against Women in West African Christian Society: Educational Imperatives", in Religion and Gender-Based Violence: West African Experience, Mercy Amba Oduyoye and Rose Mary Amenga-Etego eds (Legon: Legon Theological Studies Press, 2013): 265-283.
} 
engagement of the narrative. The moral stance of Vashti must be recognized and used as an example of how women can stand against domestic violence, immoral demands by men, and social injustice in African society.

\section{ABOUT AUTHORS}

Daniel Nii Aboagye Aryeh, PhD is the Acting Rector of Perez University College. George Sungadar Moses Wee is the Dean of the School of Business, Perez University College. He is a PhD Candidate at GIMPA, Legon.

\section{BIBLIOGRAPHY}

Assis, Elie. Chiasmus in Biblical Narrative: Rhetoric of Characterization. Prooftexts Vol. 22, No. 3 (Fall 2002): $273-$ 304. https://doi.org/10.1353/ptx.2003.0002

Azikiwe, Ohia and Uche Nkiru. The Church, Sexual Harassment and Abuse of Women in South-East Nigeria. Religion and Gender-Based Violence: West African Experience, Mercy Amba Oduyoye and Rose Mary Amenga-Etego eds (Legon: Legon Theological Studies Press, 2013): 82-98.

Bahar, Shirley M. A. Coming out as Queen: Jewish Identity, Queer Theory, and the Book of Esther. Studies in Gender and Sexuality, Vol. 13, No. 3, 167-178. http//dx.doi.org/10.1080/15240657.2012.709134.

Berger, Yitzhak. Chiasm and Meaning in 1 Chronicles. Journal of Hebrew Scriptures Vol. 14, No. 1(2014): 1-31.

Castelnuovo, Shirley. The Jewish Experience of Oppression as Portrayed in the Hebrew Bible: Leadership and Survival Strategies Jewish. Political Studies Review, Vol. 3, No. 1/2 (Spring 1991): 33-47.

Fader, Ayala. Reflection of Esther: The Politics of Jewish Ethnography. Contemporary Jewry, Vol. 27, No. 1 (October 2007), 112-136. https://doi.org/10.1007/bf02965548

Gyekye, Kwame. African Cultural Values: An Introduction. Accra: Sankofa Publishing Company, 1996.

Leroux, Neil R. Repetition, Progression, and Persuasion in Scripture. Neotestamentica, Vol. 29, No. 1 (1995): 1-25.

Mbiti, John S. Introduction to African Religion $2^{\text {nd }}$ Ed. Oxford: Heinemann Educational Publishers, 1991.

McCoy, Brad. Chiasmus: An Important Structural Device Commonly Found in Biblical Literature. www.chafer.edu/journal/back_issues/Vol\%209-2\%20ar2.pdf.

Moyer, Clinton J. The Beautiful Outside Replaces the Queen: A 'Compound Topos' in Esther 1-2 and Book 5 and 6 of Chariton's Chaereas and Callirhoe. Vetus Testamentum, 60 (2010), 601-620 doi:10.1163/156853310X527824

Nadar, Sarojini. Power, ideology and interpretation/s: Womanist and literary perspectives on the Book of Esther as resources for gender-social transformation. (Doctoral dissertation), 2003.http://hdl.handle.net/10413/3449.

Noll, Stephen F. Esther. Walter A. Elwell (ed) Baker Commentary on the Bible Based on the NIV. (Grand Rapids, Michigan: Baker Books, 1989): 328-329.

Oduyoye, Mercy Amba. Gender-Based Violence in Religiously Pluralistic Societies: The West African Experience. Religion and Gender-Based Violence: West African Experience, Mercy Amba Oduyoye and Rose Mary

Amenga-Etego eds. Legon: Legon Theological Studies Press, 2013: 1-19.

Opoku, Kofi Asare. West African Traditional Religion. Accra: FEP International Private Limited, 1978.

Oren, Drora. Esther-The Jewish Queen of Persia. Nashim: A Journal of Jewish Women's Studies \& Gender Issues, No. 18, (Fall 2009): 140-165. https://doi.org/10.2979/nas.2009.-.18.140

Stern, Elsie R. Esther and the Politics of Diaspora. The Jewish Quarterly Review, Vol. 100, No. 1 (Winter, 2010): $25-53$.

Stone, Meredith J. There's more than one way: Vashti, Esther, and women in ministry. Review \& Expositor, Vol.110, No. 1 (2013): 123-130.

Uchem, Rose. Eradicating Gender-Based Violence against Women in West African Christian Society: Educational Imperatives. Religion and Gender-Based Violence: West African Experience, Mercy Amba Oduyoye and Rose Mary Amenga-Etego eds. Legon: Legon Theological Studies Press, 2013: 265-283.

Walfish, Barry Dov. The Mordecai-Esther-Ahasuerus Triangle in Midrash and Exegesis. Prooftexts, Vol. 22, No. 3 (Fall 2002): 305-333. https://doi.org/10.1353/ptx.2003.0008

Zaeske, Susan. Unveiling Esther as a Pragmatic Radical Rhetoric. Philosophy \& Rhetoric, Vol. 33, No. 3 (2000): 193220. https://doi.org/10.1353/par.2000.0024

Zlotnick, Helena. From Jezebel to Esther: Fashioning Images of Queenship in the Hebrew Bible. Biblica, Vol. 82, No. 4 (2001): 477-495. 